\title{
Kentsel Estetiğin Muratpaşa İlçesi Örneğinde İrdelenmesi
}

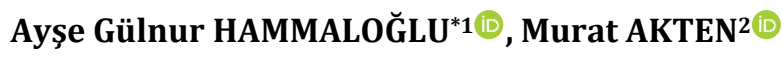 \\ 1,2Süleyman Demirel Üniversitesi, Mimarlık Fakültesi, Peyzaj Mimarlı̆̆ı Bölümü, 32260, Isparta, Türkiye
}

(Alınış / Received: 21.02.2020, Kabul / Accepted: 24.09.2020, Online Yayınlanma / Published Online: 20.12.2020)

\author{
Anahtar Kelimeler \\ Kent, \\ Algl, \\ Estetik, \\ Kentsel estetik, \\ Muratpaşa
}

\begin{abstract}
Özet: $\mathrm{Bu}$ çalışmada, çevrenin yalnızca insanın biyolojik gereksinmelerini karşılayan işlevsellik değil, aynı zamanda psikolojik, entelektüel gereksinmelerini de karşılayan estetik nitelikler de taşıması gerektiği hipotezinden yola çıkılarak kentleri oluşturan fiziksel çevrenin niteliklerinin yanı sıra taşıdıkları anlamları ve estetik anlamda nasıl algılandıklarının ortaya konulması hedeflenmiştir. Calıșmanın ana materyalini Antalya İli Muratpașa İlçesine ait Güllük Caddesi, Cumhuriyet Meydanı ve Kapalı Yol mevkileri olușturmaktadır. Çalışma alanlarına ait 33 adet fotoğraf kentsel estetiğin irdelenmesi amacıyla kullanılmıştır. Fotoğraflardaki görüntüler üzerinden kentsel estetik konusunda disiplinler arası uzman grubuna (Şehir plancısı, Peyzaj mimarı ve Yapı mimarı) foto anket ve anket çalışması gerçekleştirilmiştir. Daha sonra uzman grubu değerlendirmelerine yönelik en çok tercih edilen görüntülere ilişkin mekansal karakteristikler ortaya konulmuștur. Çıkan sonuçlarla, kentsel çevre algısı ve estetiğine yönelik düzenlemeler ve önlemler alınarak, kentin çağdaş yaşamın gereklilikleri ile birlikte uyumu sağlanacak ve böylece yașanabilir alanlar olarak gelecek kușaklara aktarılmasına katkı sağlanacaktır.
\end{abstract}

\section{Urban Aesthetic Research in Muratpasa District}

\section{Keywords}

City,

Perception,

Aesthetics,

Urban aesthetics,

Muratpaşa

\begin{abstract}
In this study, it is hypothesized that the environment should not only have functionality that meets the biological needs of human being-environment relations, but also aesthetic qualities should meet the psychological and intellectual needs. Considering this hypothesis,researched characteristics of the physical environment, their meaning and how they are perceived aesthetically. The main material of the study examined at Güllük Caddesi, Cumhuriyet Meydanı and Kapalı Yol area in Muratpasa district. 33 photographs of the study areas were used for the study of urban aesthetics.A photo questionnaire was conducted to the interdisciplinary group of experts (City planner, Landscape architect and Building architect) on urban aesthetics from images of these photographs. Then ,considering these expert group's most preferred images determined spatial distinctives.As a results, arrangements will be made for the perception and aesthetics of the urban environment and the harmony of the city with the requirements of contemporary life will be ensured.Thus, it will contribute to transfer to future generations as habitable area.
\end{abstract}

\section{Giriş}

Endüstri devrimi beraberinde kentleşmeyi de getirmiş, kentte bulunan iş imkânları, sosyal ve kültürel olanaklar insanlara cazip gelerek kırdan kente göçü her geçen gün hızlandırmıştır. Modernizm döneminde modern kent unsurlarını yansıtan altyapı çalışmaları yapılmıştır. Yapılan yeni ve gelişimci çalışmalara rağmen birçok problem de ortaya çımıştır. Bu sorunları; hızlı kentleşme ile nüfus

*ilgili yazar: aysegulnurhammaloglu06@gmail.com yığılmaları, arsa spekülasyonları ve çarpık kentleșme olarak özetlemek mümkündür.

Modernizme tepki olarak ortaya çıkan Postmodernist yaklaşımında ise, modern kentin olumsuz, yorucu, tüketici ve planlamaya dayanan yönlerine vurgu yapılmaktadır. Aslında postmodernizmin diğer alanlarda olduğu gibi, mimarlık ve kentleşme alanında da elle tutulur bir şey söylemediğini, bazı sorunların varlığını saptadığını, ancak gözle görülür kentsel ve toplumsal sorunlara çözüm üretemediğini, 
özgürlük ve demokrasi söylemlerinin ise, somut düzeyde yalnızca "söylem"den ibaret olduğu savunulmaktadır [1].

Kentsel tasarım akımlarından kentler etkilenmiş, çevre kaynakları, doğal kültürel değerler ve kent yaşam kalitesi estetik anlamda düşmüştür. Kentte yaşayan insanlar için doğa ve açık-yeşil alanlar nefes alınan, psikolojik rahatlama sağlayan vazgeçilmez mekanlar haline gelmiştir. Böylece yaşam kalitesini iyileştirme hususunda estetik anlamda sürdürülebilir kentler kavramı gündeme gelmiștir. Fakat bütüncül anlamda estetik kentleri oluşturmak oldukça güç olmuştur. Kent estetiğini etkileyen olumsuz biçimlenmeler kentin bir bütün olarak düşünülmemesinden veya bütünlüğün bilincine varılmadan sorunlara çözümler aranmasından kaynaklanmaktadır [2].

Estetik kentler aynı zamanda bir kimliğe sahip kent imajı olușmuș kentlerdir. Kimliği olușmuș kentler ise, diğer kentlerden ayrlarak, kent sakinlerine kültürlerini yansıtan ve tercih ettikleri yaşam alanlarında çevre değerleriyle yaşama bilinci sunmaktadır.

Bu çalışma ile kullanıcıları tarafından çevresel algı ve kent estetiğine yönelik görüşlerinin ortaya konulması amacıyla, Antalya kentinde aktif olarak kullanılan Güllük caddesi ve devamında yer alan Cumhuriyet Meydanı, Kapalı Yol mevkileri çalışma alanı olarak belirlenmiștir.

\section{Materyal ve Metot}

\subsection{Materyal}

Araştırma alanı olarak Antalya kentinin Muratpaşa ilçesinde, aktif olarak kullanılan Güllük Caddesi, Cumhuriyet Meydanı ve Kapalıyol mevki belirlenmiştir.

Çalışma alanının Türkiye'deki konumu Şekil 1 ve Antalya İli içindeki konumu ise Şekil 2'de gösterilmektedir.

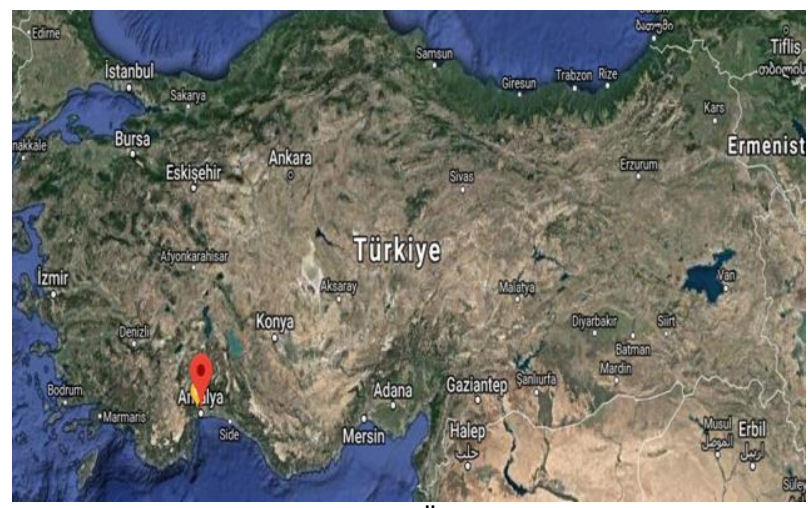

Şekil 1. Antalya ilinin Türkiye Üzerindeki Konumu

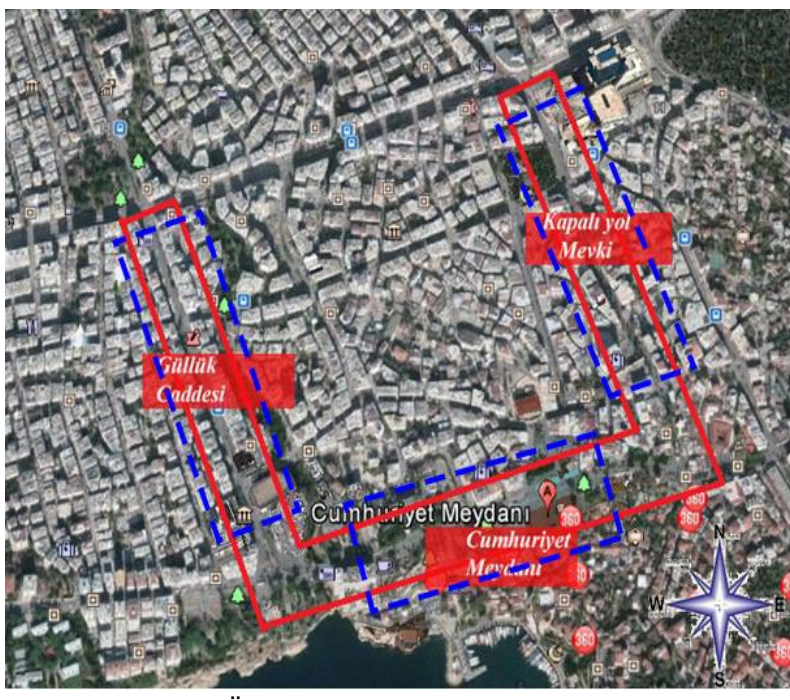

Şekil 2. Antalya Üzerinde Çalışma Alanının Konumu

Tablo 1'de çalışma alanına ait harita konumu, coğrafi konum ve Semt/Mahalle bilgileri verilmiştir.

Tablo 1. Çalıșma Alanının Koordinat ve Harita Konumu

\begin{tabular}{ccc}
\hline $\begin{array}{c}\text { Cumhuriyet } \\
\text { Meydanı }\end{array}$ & $\begin{array}{c}\text { Güllük Caddesi } \\
\text { (Anafartalar } \\
\text { Caddesi) }\end{array}$ & $\begin{array}{c}\text { Kapalı Yol } \\
\text { (Eski Şarampol } \\
\text { Caddesi) }\end{array}$ \\
\hline Enlem: & Enlem: & Enlem: \\
36.8865 & 36.887444 & 36.8929 \\
Boylam: & Boylam: & Boylam: \\
30.7031 & 30.696789 & 30.7036 \\
\hline Kuzey: & Kuzey: & Kuzey: \\
$36^{\circ} 53^{\prime} 11^{\prime \prime}$ & $36^{\circ} 53^{\prime} 14.7984^{\prime \prime}$ & $36^{\circ} 53^{\prime} 21^{\prime \prime}$ \\
Doğu: & Doğu: & Doğu: \\
$30^{\circ} 42^{\prime} 11^{\prime \prime}$ & $30^{\circ} 41^{\prime} 48.4404^{\prime \prime}$ & $30^{\circ} 42^{\prime} 16^{\prime \prime}$ \\
koordinatları & koordinatları & koordinatları \\
\hline Selçuk Mahallesi & Deniz Mahallesi & Muratpaşa \\
Muratpaşa İlçesi & Muratpaşa İlçesi & Mahallesi \\
\hline
\end{tabular}

\subsection{Metot}

Çevresel değerlendirme süreci, çevre niteliklerinin algılanması sonucunda belirli seçimler yaparak davranışlarda bulunma ve belirli kararlar verme süreci" olarak tanımlanmaktadır. Bu değerlendirme sürecinde, birey estetik tavır takınarak haz aldığı çevresine, estetik yargısını biçimsel ve simgesel olarak iki şekilde yüklemektedir [3].

Kentlerde estetik boyut değerlendirilirken genellikle iki farklı yöntem kullanılmaktadır. Bunlardan ilki sembolik yaklaşımlara dayanan öznel anlamda eleştiri, yorum yapılarak kullanılan anketler ve şematik anlatımlarken (foto-anketler), diğeri ise biçimsel yaklaşımlara dayanan nesnel anlamda analizler yapılarak ortaya koyulan entropidir.

Her durumda da algılanan çevrenin, normlar, fikirler, standartlarla değerlendirildiğini belirten Rapoport ise, çevresel kalite profillerinin ve bunların pozitif veya negatif değerlendirmelerinin, çevresel kalitenin bileşenleri ve bunların dereceleri ile değişebildiğini savunmaktadır. Bireyin çevreyi algılama ve 
değerlendirme süreci için Rapoport'un geliştirdiği model Şekil 3'te verilmiştir.

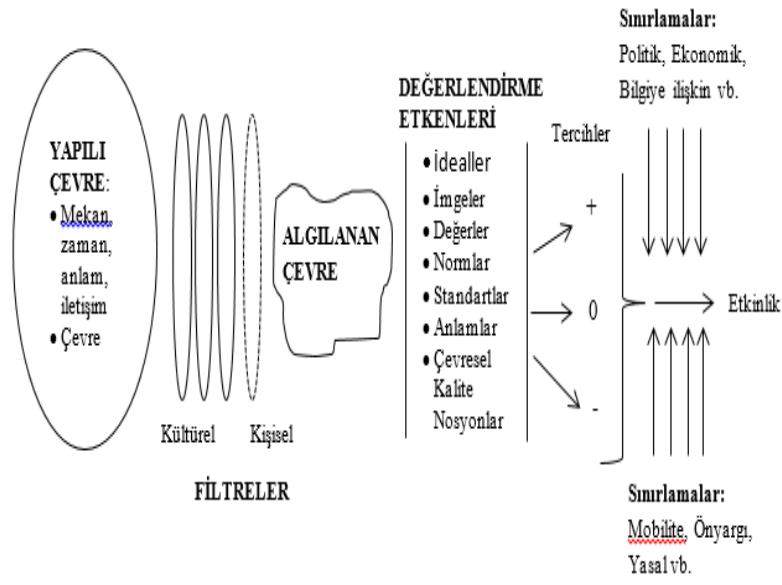

Şekil 3. Rapoport'un çevresel bir uyara karşı temel değerlendirme süreci modeli [4].

Yukarıdaki bilgiler ıșığında çalıșmada yöntem olarak anket ve foto-anket yöntemi kullanılmıştır. Çalışmada foto-anket uygulamasının kullanılmasının temel nedeni hızlı, güvenilir ve katılımcıların fikirlerini daha rahat belirtecekleri ortamı sağlamasıdır. Katılımcılara yanıtlarını aktarabilecekleri bir form oluşturularak foto-anketler değerlendirilmiştir.

Anketlerin içeriği, katılımcıların demografik özelliklerini içeren sorular ve çalışma alanlarını kullanma tercihlerini yansıtan sorularla, çalışma alanındaki mekânsal öğelere yönelik estetik niteliği ortaya koyan fotoğraf analizlerinden oluşmaktadır. Öncelikle alanının resimleri profesyonel makine yardımıyla çekilmiştir. Fotoğrafların çekiminde mevsimsel döngü, alanın kullanım yoğunluğunu ve kişilerin psikolojileri ve algılarını etkilediği için çekim ve alan analizleri, 6 ay ara ile kış ve yaz aylarında gerçekleştirilmiştir.

Uzman anket katılımcıları peyzaj mimarlığı, yapı mimarlığı, şehir ve bölge planlama alanında eğitim görmüş ve eğitimine devam eden katılımcılardan oluşmaktadır. Kentsel estetik konusu interdisipliner çalışma gerektirdiği ve bu üç disiplinin de konusu olduğu için uzman anket katılımcıları üç disiplinden de seçilmiştir.

Anket yönteminde 100 uzman anket katılımcısına, 38 soru yöneltilmiştir (Ek A). Anket demoğrafik özellikler, alan kullanıcı izlenimleri, alan kullanım amaçları, kullanıcı istekleri ve alanda istenen düzenlemeleri kapsamaktadır. Anket soruları üç ayrı alan için de yapılmış ve böylece alanları kıyaslama imkanı bulunmuştur. Anket soruları belirlenirken yerli ve yabancı literatür taraması yapılmış ve bu çalışmalardan yararlanarak çalışmanın temeli oluşturulmuştur.
Foto-anket yöntemi ise uzman anket katılımcllarına uygulanmıştır. Alanda yerinde gözlem yapıldıktan sonra fotoğraflar çekilmiștir. Fotoğraf çekimi esnasında objektif davranılmış katılımcıları etkileyebilecek herhangi bir eğilim gösterilmemiştir. Fotoğraf çekimlerinde alanın görsel niteliğini daha iyi ortaya koymak için profesyonel makine olan Canon EOS 5D Mark IV kullanılmıştır. Araştırmada ele alınan alanı görsel açıdan ifade edecek şekilde 500 adet fotoğraf çekilmiştir. Elde edilen bu fotoğraflar arasından uzman kiși eșliğinde foto-ankette yer alan 33 fotoğraftan 29'u seçilmiștir (Ek B). Kalan 4 fotoğraf ise alan dıșı seçilmiştir. Anket uzman katılımcılarından alan dışı 4 fotoğraf ile alandan alınan diğer 4 fotoğrafı ikili gruplar halinde kıyaslanarak yanıt vermeleri istemiştir. Akabinde yer alan fotoğraflar ise Güllük Caddesi, Cumhuriyet Meydanı ve Kapalı Yol mevkinde yer alan benzer kullanımları içermektedir. Yine uzman anket katılımcılarından benzer kullanımları kıyaslayarak yanıt vermeleri ve her üç fotoğrafi kendi arasında mukayese ederek estetik açısından görüşlerini sunmaları istenmiştir. Fotoğraflar sunulurken katılımcılardan fotoğrafları hoş/sıkıcı, ilginç/ilginç değil, farklı/monoton, abartılı/silik, uyumlu/uyumsuz olarak 7 li Likert Ölçeği kullanılarak değerlendirmeleri istenmiștir. $\mathrm{Bu}$ parametreler birbirinin zıttı konumundadır. Örneğin 1, 2, 3 oyları hoș puanını belirtirken 0 oyu fikrim yok $-1,-2,-3$ oyları ise sıkıcı puanını belirlemektedir. Dolayısıyla 5 parametre kullanarak 7'li Likert Ölçeğinde, 5 parametrenin zitları hakkında da bilgi sahibi olunmuştur. Dolayısıyla fotoğrafları 10 parametrede değerlendirme firsatı elde edilmiştir.

Değerlendirme yapılırken kullanılan puanlama şablonu tabloda verilmiştir (Tablo 2).

Tablo 2. Parametre puanlama değerlendirme şablonu

\begin{tabular}{|c|c|c|c|c|c|}
\hline & Hos & İlginc & Farklı & Abartılı & Uyumlu \\
\hline 3 & Çok hoş & Çok ilginç & $\begin{array}{c}\text { Çok } \\
\text { farklı }\end{array}$ & $\begin{array}{c}\text { Çok } \\
\text { abartilı }\end{array}$ & $\begin{array}{c}\text { Çok } \\
\text { uyumlu }\end{array}$ \\
\hline 2 & Hoş & İlginç & Farklı & Abartılı & Uyumlu \\
\hline 1 & Az hoș & Az ilginç & Az farklı & $\begin{array}{c}\mathrm{Az} \\
\text { abartılı }\end{array}$ & $\begin{array}{c}\mathrm{Az} \\
\text { uyumlu }\end{array}$ \\
\hline $\mathbf{0}$ & $\begin{array}{l}\text { Fikrim } \\
\text { yok }\end{array}$ & $\begin{array}{c}\text { Fikrim } \\
\text { yok }\end{array}$ & $\begin{array}{c}\text { Fikrim } \\
\text { yok }\end{array}$ & $\begin{array}{l}\text { Fikrim } \\
\text { yok }\end{array}$ & $\begin{array}{l}\text { Fikrim } \\
\text { yok }\end{array}$ \\
\hline-1 & Az sıkıcı & $\begin{array}{l}\text { Az ilginç } \\
\text { değil }\end{array}$ & $\begin{array}{c}\mathrm{Az} \\
\text { monoton }\end{array}$ & Az silik & $\begin{array}{c}\mathrm{Az} \\
\text { uyumsuz }\end{array}$ \\
\hline-2 & Sikıcı & $\begin{array}{l}\text { İlginç } \\
\text { değil }\end{array}$ & Monoton & Silik & Uyumsuz \\
\hline-3 & $\begin{array}{c}\text { Çok } \\
\text { Sikıcı } \\
\end{array}$ & $\begin{array}{c}\text { Çok ilginç } \\
\text { değil }\end{array}$ & $\begin{array}{c}\text { Çok } \\
\text { Monoton } \\
\end{array}$ & Çok silik & $\begin{array}{c}\text { Çok } \\
\text { uyumsuz }\end{array}$ \\
\hline
\end{tabular}

\section{Bulgular}

\subsection{Demografik özelliklere ait bulgular}

Toplam 100 gönüllü uzman birey araştırma kapsamında anket uygulamasına katılmıştır. Tablo 3'te demografik bilgilere ait kişi sayısı ve yüzde tablosu verilmiştir. 
Tablo 3. Demografik bilgilere ait kiși dağılımları ve yüzde tablosu

\begin{tabular}{|c|c|c|}
\hline Demografik Özellikler & Kiși & Yüzde (\%) \\
\hline \multicolumn{3}{|l|}{ Cinsiyetiniz? } \\
\hline Kadın & 51 & 51 \\
\hline Erkek & 49 & 49 \\
\hline Toplam & 100 & 100 \\
\hline \multicolumn{3}{|l|}{ Yașınız? } \\
\hline $18-25$ & 52 & 52 \\
\hline $26-33$ & 36 & 36 \\
\hline $34-41$ & 7 & 7 \\
\hline $42-49$ & 3 & 3 \\
\hline $50-57$ & 1 & 1 \\
\hline $58-65$ & 1 & 1 \\
\hline $65+$ & 0 & 0 \\
\hline Toplam & 100 & 100 \\
\hline \multicolumn{3}{|l|}{ Eğitim durumunuz? } \\
\hline Lisans (Üniversite) & 56 & 56 \\
\hline Yüksek Lisans & 36 & 36 \\
\hline Doktora & 8 & 8 \\
\hline Toplam & 100 & 100 \\
\hline \multicolumn{3}{|l|}{ İș durumunuz? } \\
\hline Çalışıyor & 30 & 30 \\
\hline Çalışmiyor & 70 & 70 \\
\hline Toplam & 100 & 100 \\
\hline \multicolumn{3}{|l|}{ Bölümünüz? } \\
\hline Yapı Mimarlı̆gı & 31 & 31 \\
\hline Peyzaj Mimarlığı & 40 & 40 \\
\hline Şehir ve Bölge Planlama & 29 & 29 \\
\hline Toplam & 100 & 100 \\
\hline \multicolumn{3}{|l|}{ Ekonomik geliriniz? } \\
\hline$\ldots<2.500$ & 66 & 66 \\
\hline $2.500-5.000$ & 14 & 14 \\
\hline $5.000<\ldots$ & 20 & 20 \\
\hline Toplam & 100 & 100 \\
\hline
\end{tabular}

Anket katılımcılarının soruları bağımsız olarak yanıtlamaları açısından 18 yaş üstü katılımcı profili ankete dahil edilmiştir. Katılımcıların çoğunluğunun 18-25 yaş aralığında olduğu görülmektedir. Uzman anket katılımcılarının çoğunun çalışmadığı görülmektedir. Lisans, yüksek lisans ya da doktora düzeyinde eğitim almakta olduğundan dolayıdır. Görüldüğü üzere anket katılımcllarının çoğunluğu lisans düzeyinde eğitim almıştır. Katılımcıların çoğunun peyzaj mimarlığı bölümünde uzman olduğu görülmektedir. Ekonomik gelirine bakıldığında çoğunluğunun 2.500'ün altında gelire sahip olduğu görülmektedir (Tablo 3).

\subsection{Kavramsal temellere ait bulguları}

Anket katılımcılarının; kavramsal temellere yönelik kullanıcı tercihleri irdelenmiştir ve estetik bir meydan ve estetik bir cadde nasıl olmalı sorusunun yanıtı aranmıştır. Tablo 4.'de kavramsal temellere ait kişi sayısı ve yüzde tablosu verilmiştir.

Anket katılımcllarının estetik bir meydan ve estetik bir cadde nasıl olmalıdır sorusuna; Hem estetik bir meydan hem de estetik bir cadde göze hoş görünmeli yanıtını çoğunlukla verdiği görülmektedir (Tablo 4).
Tablo 4. Kavramsal temellere ait kullanıcı istekleri

\begin{tabular}{ccc}
\hline $\begin{array}{c}\text { Kavramsal Temellere Yönelik } \\
\text { Kullanıcı Tercihleri }\end{array}$ & Kişi & Yüzde(\%) \\
\hline Estetik meydan sizce nasıl olmalıdır? & & \\
Göze hoş görünmeli & 26 & 26 \\
Birçok kullanım (fonksiyon)içermeli & 15 & 15 \\
Doğal malzemeler kullanılmalı & 9 & 9 \\
Çevre içinde farkedilmeli & 12 & 12 \\
Sanatsal değeri olmalı & 15 & 15 \\
Estetik bir cadde sizce nasıl olmalıdır? & & \\
Göze hoş görünmeli & 55 & 55 \\
Birçok kullanım (fonksiyon)içermeli & 21 & 21 \\
Doğal malzemeler kullanılmalı & 6 & 6 \\
Çevre içinde farkedilmeli & 8 & 8 \\
Sanatsal değeri olmalı & 10 & 10 \\
\hline
\end{tabular}

\section{3. Çalışma alanlarına ait bulgular}

Anket katılımclarının alan kullanma tercihleri sorgulanmaktadır. Tablo 5 'te alan kullanım sıklıkları ve tercih edilen saat dilimleri kişi sayıları ve yüzde dağılımları ile birlikte gösterilmektedir.

\begin{tabular}{|c|c|c|c|c|c|c|}
\hline \multirow{2}{*}{$\begin{array}{c}\begin{array}{c}\text { Alan Kullanım } \\
\text { Tercihleri }\end{array} \\
\text { Alanı } \\
\text { kullanma } \\
\text { sıklığınız? }\end{array}$} & \multicolumn{2}{|c|}{$\begin{array}{c}\text { Kapalı } \\
\text { Yol }\end{array}$} & \multicolumn{2}{|c|}{$\begin{array}{c}\text { Cumhuriyet } \\
\text { Meydanı }\end{array}$} & \multicolumn{2}{|c|}{$\begin{array}{c}\text { Güllük } \\
\text { Caddesi }\end{array}$} \\
\hline & Kişi & (\%) & Kişi & (\%) & Kişi & (\%) \\
\hline $\begin{array}{l}\text { Hergün } \\
\text { (Çok sık) }\end{array}$ & 9 & 9 & 8 & 8 & 16 & 16 \\
\hline $\begin{array}{l}\text { Haftada iki } \\
\quad(\mathrm{S} ı \mathrm{k})\end{array}$ & 15 & 15 & 8 & 8 & 9 & 9 \\
\hline $\begin{array}{l}\text { Haftada bir } \\
\text { (Genellikle) }\end{array}$ & 35 & 35 & 38 & 38 & 30 & 30 \\
\hline $\begin{array}{l}\text { Ayda iki-üç } \\
\text { (Bazen) }\end{array}$ & 18 & 18 & 15 & 15 & 17 & 17 \\
\hline $\begin{array}{l}\text { Ayda bir } \\
\text { (Seyrek) }\end{array}$ & 6 & 6 & 13 & 13 & 11 & 11 \\
\hline $\begin{array}{l}\text { İki ayda bir } \\
\text { (Çok seyrek ) }\end{array}$ & 14 & 14 & 14 & 14 & 13 & 13 \\
\hline İlk defa & 3 & 3 & 4 & 4 & 4 & 4 \\
\hline $\begin{array}{c}\text { Alanı hangi } \\
\text { saat } \\
\text { dilimlerinde } \\
\text { daha çok } \\
\text { kullanıorsun } \\
\text { uz? }\end{array}$ & & & & & & \\
\hline $07.00-12.00$ & 8 & 8 & 9 & 9 & 16 & 16 \\
\hline $12.00-18.00$ & 61 & 61 & 56 & 56 & 54 & 54 \\
\hline $18.00-24.00$ & 65 & 65 & 70 & 70 & 75 & 75 \\
\hline $24.00-07.00$ & 1 & 1 & 2 & 2 & 1 & 1 \\
\hline
\end{tabular}

Anket katılımcıları Kapalı Yolu kullanma sıklığınız nedir sorusuna; katılımcıların haftada bir (genellikle) cevabını çoğunlukla verdiği görülmektedir. Cumhuriyet Meydanını kullanma nedir sıklığınız sorusuna; katılımcıların haftada bir(genellikle) yanıtını çoğunlukla verdiği görülmektedir. Güllük Caddesini kullanma sıklığınız nedir sorusuna; en çok yanıtın haftada bir (genellikle) olduğu görülmektedir (Tablo 5).

Katılımcılara hangi zaman diliminde Kapalı Yolu kullanmayı tercih edersiniz sorusu sorulduğunda; çoğunluğun 18.00-24.00 saat dilimlerinde kullanmayı tercih ettiği görülmektedir. Cumhuriyet Meydanını hangi zaman diliminde kullanmayı tercih edersiniz sorusu sorulduğunda; çoğunluğun 18.00-24.00 saat dilimlerinde kullanmayı tercih ettiği görülmektedir. 
Güllük Caddesini hangi zaman diliminde kullanmayı tercih edersiniz sorusu sorulduğunda; çoğunluğun 18.00-24.00 saat dilimlerinde kullanmayı tercih ettiği görülmektedir. Dolayısıyla üç alanın da anket katılımcıları tarafından çoğunlukla 18.00-24.00 saat dilimleri arasında kullanıldığı görülmektedir (Tablo 5).

Anket katılımcılarının alanın bıraktığı etki ve izlenimler sorgulanmaktadır. Tablo 6'da alaların uyandırdığı psikolojik etki, fonksiyonel memnuniyet durumu, en beğenilen karakteristik özellikler kişi sayıları ve yüzde dağılımları ile birlikte gösterilmektedir.

Tablo 6. Alanların kullanıcılarda bıraktığı izlenim

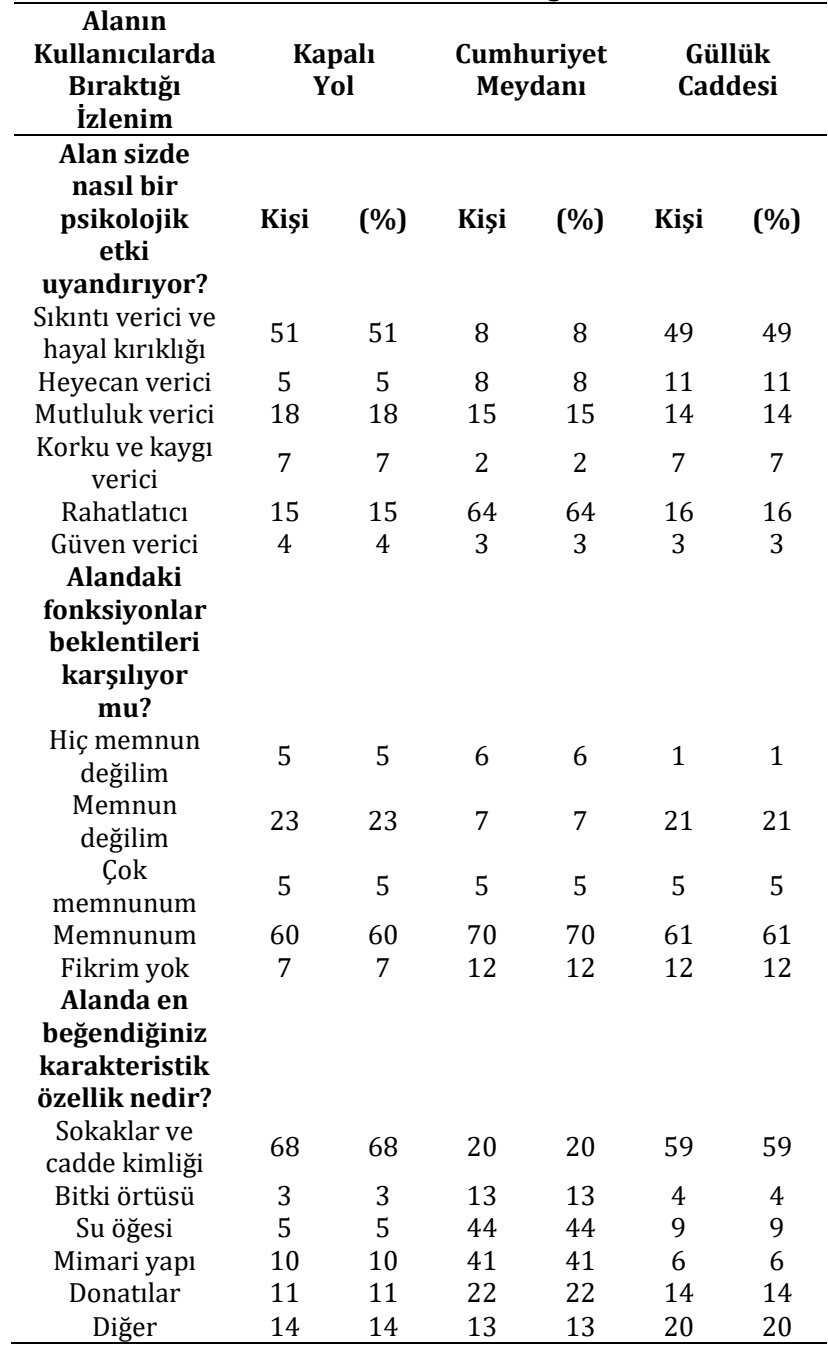

Anket katılımcılarına Kapalı Yol sizde nasıl bir psikolojik etki uyandırıyor sorusu sorulduğunda; katılımcıların çoğunda Kapalı yolun psikolojik olarak sıkıntı verdiği ve hayal kırıklığı yaşattığı görülmektedir. Cumhuriyet Meydanını sizde nasıl bir psikolojik etki uyandırıyor sorusu sorulduğunda; katılımcıların çoğunda Cumhuriyet Meydanının psikolojik olarak rahatlama etkisi yarattığı görülmektedir. Güllük Caddesi sizde nasıl bir psikolojik etki uyandırıyor sorusu sorulduğunda; katılımcıların çoğunda Güllük Caddesinin psikolojik olarak sıkıntı verdiği ve hayal kırıklığı yaşattığı görülmektedir (Tablo 6).

Anket katılımcılarına Kapalı Yoldaki fonksiyonlar beklentinizi karşıllyor mu sorusu sorulduğunda; katılımcların çoğu memnun yanıtı vermiştir. Cumhuriyet Meydanındaki fonksiyonlar beklentinizi karşılıyor mu sorusu sorulduğunda; katılımcıların çoğu memnun yanıtı vermiştir. Güllük Caddesindeki fonksiyonlar beklentinizi karşllyor mu sorusu sorulduğunda; katılımcıların çoğu memnun yanıtı vermiștir. Dolayısıyla her üç alan kullanıcıları da alanlarda bulunan fonksiyonlardan memnunum yanıtını vermiştir ve alanların beklentileri karşıladığı görülmektedir (Tablo 6).

Katılımcılara Kapalı Yolda en beğendiğiniz karakteristik özellik nedir sorusu sorulduğunda; katılımcıların çoğunluğun sokaklar ve cadde kimliği yanıtı verdiği görülmektedir. Cumhuriyet Meydanında en beğendiğiniz karakteristik özellik nedir sorusu sorulduğunda; katılımcıların çoğunluğun su öğesi yanıtı verdiği görülmektedir. Gülük Caddesinde en beğendiğiniz karakteristik özellik nedir sorusu sorulduğunda; katılımcıların çoğunluğun sokaklar ve cadde kimliği yanıtı verdiği görülmektedir (Tablo 6).

Anket katılımcılarının alanları kullanım amaçları irdelenmektedir. Tablo 7'de alanların kullanım amaçları kişi sayıları ve yüzde dağılımları ile birlikte gösterilmektedir.

Tablo 7. Alanların kullanım amaçları

\begin{tabular}{ccccccc}
\hline $\begin{array}{c}\text { Alan } \\
\text { Kullanım } \\
\text { Amaçları }\end{array}$ & $\begin{array}{c}\text { Kapalı } \\
\text { Yol }\end{array}$ & $\begin{array}{c}\text { Cumhuriyet } \\
\text { Meydanı }\end{array}$ & $\begin{array}{c}\text { Güllük } \\
\text { Caddesi }\end{array}$ \\
\hline $\begin{array}{c}\text { Alanı } \\
\text { kullanma } \\
\text { amacınız } \\
\text { nelerdir? }\end{array}$ & Kişi & (\%) & Kişi & (\%) & Kişi & (\%) \\
$\begin{array}{c}\text { Temiz hava } \\
\text { almak }\end{array}$ & 6 & 6 & 48 & 48 & 4 & 4 \\
$\begin{array}{c}\text { Dinlenmek } \\
\text { ve }\end{array}$ & 5 & 5 & 60 & 60 & 5 & 5 \\
$\begin{array}{c}\text { rahatlamak } \\
\text { Alışveriş } \\
\text { yapmak } \\
\text { Etrafı }\end{array}$ & 73 & 73 & 7 & 7 & 67 & 67 \\
$\begin{array}{c}\text { seyretmek } \\
\text { Birileriyle } \\
\text { buluşmak } \\
\text { Günlük } \\
\text { işlerimi }\end{array}$ & 74 & 34 & 45 & 45 & 23 & 23 \\
halletmek \\
Diğer
\end{tabular}

Kapalı Yolu kullanma amacınız nelerdir sorusu sorulduğunda; katılımcıların Kapalı Yolu en çok alışveriş yapmak amacıyla kullanıldığı görülmektedir. Cumhuriyet Meydanını kullanma amacınız nelerdir sorusu sorulduğunda; katılımcıların Cumhuriyet Meydanını en çok dinlenmek ve rahatlama amacıyla kullanıldı̆̆ görülmektedir. Güllük Caddesini kullanma amacınız nelerdir sorusu sorulduğunda; katılımcıların Güllük Caddesini en çok alışveriş 
yapmak amacıyla kullanıldığı görülmektedir (Tablo 7).

Anket katılımcılarının alanlara yönelik istekleri ve gerekli gördüğü düzenlemeler saptanmıștır. Tablo 8'de alanlarda kullanıcı istek ve gerekli bulunan düzenlemeler kişi sayıları ve yüzde dağılımları ile birlikte gösterilmektedir.

Tablo 8. Alan kullanıcı istekleri

\begin{tabular}{ccccccc}
\hline $\begin{array}{c}\text { Kullanıcının } \\
\text { İstekleri }\end{array}$ & $\begin{array}{c}\text { Kapalı } \\
\text { Yol }\end{array}$ & \multicolumn{2}{c}{$\begin{array}{c}\text { Cumhuriyet } \\
\text { Meydanı }\end{array}$} & $\begin{array}{c}\text { Güllük } \\
\text { Caddesi }\end{array}$ \\
\hline $\begin{array}{c}\text { Alanın nasıl } \\
\text { olmasını }\end{array}$ & Kişi & $\mathbf{( \% )}$ & Kişi & $\mathbf{( \% )}$ & Kişi & $\mathbf{( \% )}$ \\
isterdiniz? & & & & & & \\
Daha renkli & 30 & 30 & 62 & 62 & 26 & 26 \\
Daha renksiz & 0 & 0 & 1 & 1 & 1 & 1 \\
Daha kompleks & 7 & 7 & 7 & 7 & 41 & 41 \\
Daha basit & 7 & 7 & 0 & 0 & 7 & 7 \\
Daha büyük & 36 & 36 & 60 & 60 & 8 & 8 \\
Daha küçük & 1 & 1 & 0 & 0 & 0 & 0 \\
Daha doğal & 19 & 19 & 24 & 24 & 18 & 18 \\
Daha yapay & 7 & 7 & 0 & 0 & 0 & 0 \\
\hline
\end{tabular}

Kapalı Yolun nasıl olmasını isterdiniz sorusu sorulduğunda; katılımcıların çoğunluğunun daha büyük yanıtı verdiği görülmektedir. Cumhuriyet Meydanının nasıl olmasını isterdiniz sorusu sorulduğunda; katılımcıların çoğunluğunun daha renkli yanıtı verdiği görülmektedir. Güllük Caddesinin nasıl olmasını isterdiniz sorusu sorulduğunda; katılımcıların çoğunluğunun daha kompleks yanıtı verdiği görülmektedir (Tablo 8)

Anket katılımcılarına Kapalı Yolda hangi düzenlemelere yer verilmelidir sorusu sorulduğunda; katılımcıların çoğunluğunun Kapalı Yolda bitki düzenlemesine (peyzaj çalışmalarına) yer verilmeli yanıtını verdiği görülmektedir (Şekil 4).

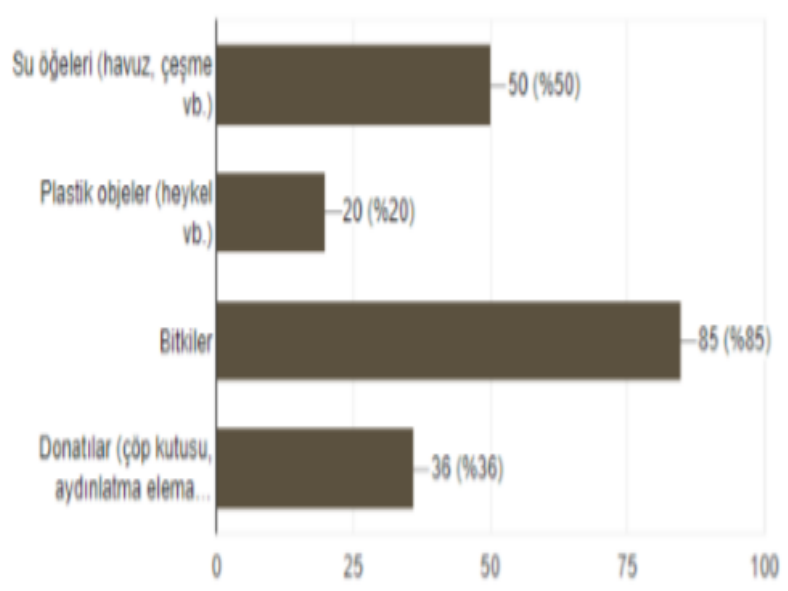

Şekil 4. Kapalı Yolda İstenen Düzenleme Elemanları (\%)

Anket katılımcılarına Cumhuriyet Meydanında hangi düzenlemelere yer verilmelidir sorusu sorulduğunda; katılımcıların çoğunluğunun Cumhuriyet Meydanında bitki düzenlemesine (peyzaj çalışmalarına) yer verilmeli yanıtını verdiği görülmektedir (Şekil 5).

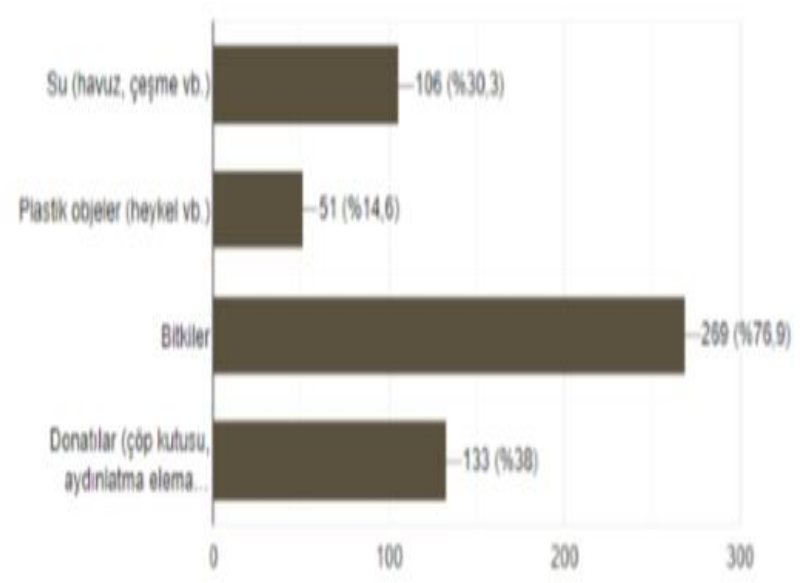

Şekil 5. Cumhuriyet Meydanında İstenen Düzenleme Elemanları(\%)

Anket katılımclarına Güllük Caddesinde hangi düzenlemelere yer verilmelidir sorusu sorulduğunda; katılımcıların çoğunluğunun Güllük caddesinde bitki düzenlemesine (peyzaj çalışmalarına) yer verilmeli yanıtını verdiği görülmektedir (Şekil 6).

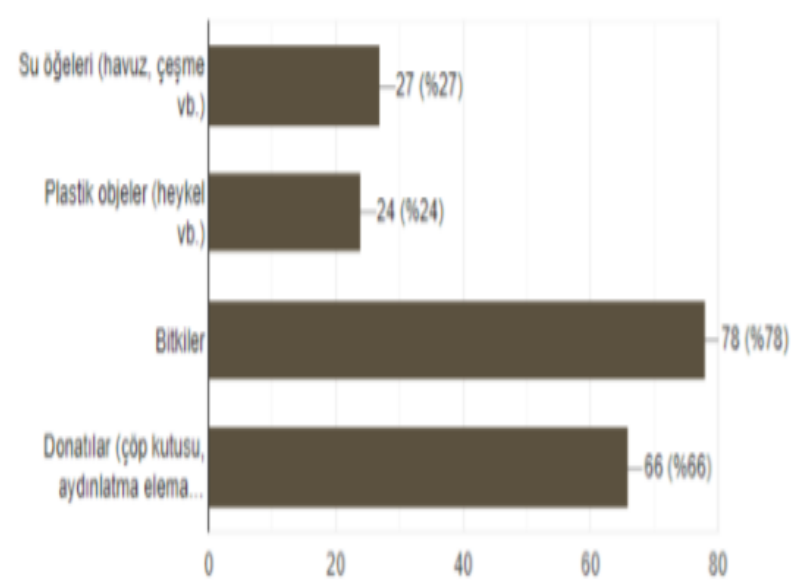

Şekil 6. Güllük Caddesinde İstenen Düzenleme Elemanları (\%)

Dolayısıyla anket katılımcıları tarafından her üç alanda da çoğunlukla bitki düzenlemesine (peyzaj çalışmalarına) yer verilmeli yanıtı verdiği görülmektedir.

Kapalı yolda hoşlandığınız şeyler nedir açık uçlu sorusuna genellikle alışveriş, hareketlilik ve kalabalık, trafiğe kapalı olması, erişim ve ulaşılabilirlik, cadde kimliği, konum ve mimari yapısı gibi yanıtlar gelmiștir. Kapalı yolda hoşlanmadığınız şeyler açık uçlu sorusuna genellikle kalabalık, dar, yetersiz, çarpık kentleşme, sıkıcı, estetik değil, işlevsiz, esnaf ve seyyar satıcılar, güvensiz, otopark sorunu, donatı eksikliği, gürültü, bakımsız gibi yanıtlar gelmiştir.

Cumhuriyet Meydanından hoşlandığınız şeyler açık uçlu sorusuna genellikle manzara, heykel, deniz, sakinlik ve huzur, modern görüntüsü, binalardan arınmış sakin hali, röper noktalardan biri 
olması(bağlantı noktası), temiz hava ve mimari yapı yanıtları gelmiștir. Cumhuriyet Meydanından hoşlanmadığınız şeyler açık uçlu sorusuna genellikle beton yığını, bitki az, peyzaj eksik, fonksiyonel yetersizlik, otopark sorunu, donatı yetersizliği, estetik değil, yapay, gölge yok, sert zemin rengi ve dokusu, dilenci ve falcılar gibi yanıtlar gelmiștir.

Güllük caddesinden hoşlandığınız şeyler açık uçlu sorusuna genellikle alışveriş, gezmek, işlek cadde olması, erișim ve ulașım gibi yanıtlar gelmiștir. Güllük caddesinden hoşlanmadığınız şeyler açık uçlu sorusuna kalabalık, kaldırım ve seyyar satıcılar, fonksiyonel yetersizlik, trafik, estetik değil, dar, trafiğe kapatılmalı, mimarisi, donatılar, yapay, bitki eksikliği gibi yanıtlar gelmiştir.

\subsection{Foto-anket sonucuna göre en yüksek ve en düşük puanı alan fotoğraflar}

Fotoğraflar kullanılarak yapılan foto-anket sonucuna göre en yüksek ve en düşük puanı alan fotoğraflar belirlenirken 3, 2, 1 oylarının toplamı en yüksek puanı belirlerken $-1,-2,-3$ oylarının toplamı ise en düşük puanı belirlemektedir. 0 oyları ise hesaplamalara dahil edilmemiştir.

Yöntem kısmında bahsedildiği üzere hoş/sıkıcl, ilginç/ilginç değil, farklı/monoton, abartılı/silik, uyumlu/uyumsuz parametreleri kullanılmıștır ve bu parametreler birbirinin zıttı konumundadır. Örneğin 1, 2, 3 oyları hoş puanını belirtirken 0 oyu fikrim yok $-1,-2,-3$ oyları ise sıkıcı puanını belirlemektedir. Dolayısıyla da en yüksek puanı alan hoş fotoğraf aynı zamanda en az puanı alan sıkıcı fotoğraf konumunda da olabilir. Aynı şekilde en yüksek puanı alan sıkıcı fotoğraf aynı zamanda en az puanı alan hoş fotoğraf konumunda da olabilir. Fakat nadir olarak 0 oyları bu durumu değiștirebilmektedir. Foto-anket sonucuna göre en yüksek ve en düşük puanı alanı alan fotoğraf ve kişi oy sayıları Tablo 9' da gösterilmektedir.

Tablo 9. En Yüksek Ve En Düșük Puanlama Sonuçları

\begin{tabular}{ccccc}
\hline & \multicolumn{2}{c}{ En Yüksek Puan } & \multicolumn{2}{c}{ En Düşük Puan } \\
\hline & Kişi & Fotoğraf & Kişi & Fotoğraf \\
Sayısı: & Kodu: & Sayısı: & Kodu: \\
Hoş & 99 & F2 & 19 & F3 \\
Sıkıcı & 71 & F3 ve F15 & 1 & F2 \\
İlginç & 90 & F22 & 14 & F15 \\
Illginç değil & 72 & F3 & 2 & F22 \\
Farklı & 89 & F22 & 13 & F3 \\
Monoton & 73 & F3 & 3 & F22 \\
Abartılı & 71 & F32 & 17 & F26 \\
Silik & 58 & F10 ve F20 & 9 & F13 \\
Uyumlu & 99 & F8 & 15 & F3 \\
Uyumsuz & 75 & F3 & 0 & F8 \\
\hline
\end{tabular}

Foto-anket sonucuna göre en yüksek ve en düşük fotoğraflar Şekil 7.'de gösterilmektedir.
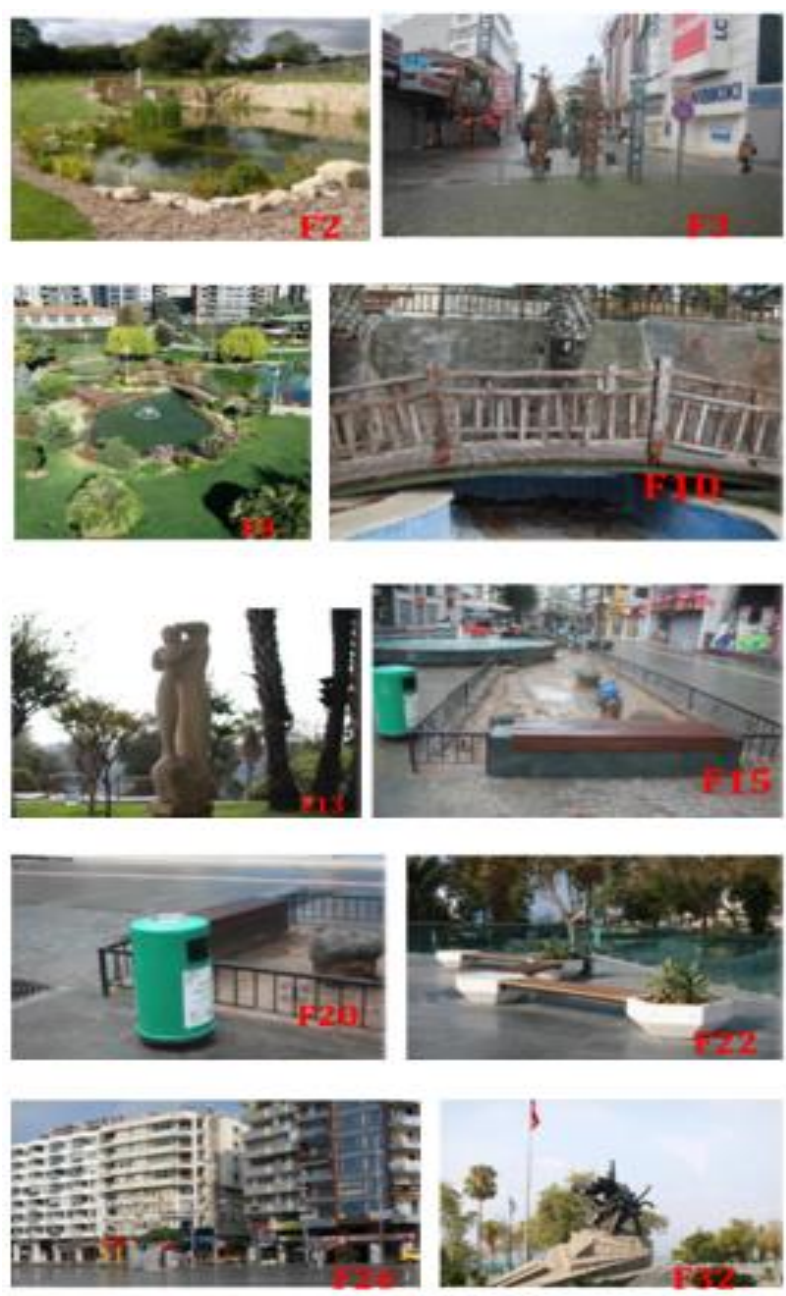

Şekil 7. En yüksek ve en düşük puanı alan fotoğraflar

Foto-anket parametreleri incelendiğinde; F2 kodlu fotoğraf hoş parametresinde en yüksek(99) sıkıcı parametresinde en düşük (1) puanı almıştır. F2 kodlu fotoğraf doğala yakın bir tasarım içermektedir ve informal çizgiler hakimdir. Doğallık özelliğine sahip çevrenin birçok materyal ile uyumunun kolay olduğu ve bitki türlerinin duyusal algı özelliklerinin kombinasyonunun tasarımlarda çok fazla tercih sebebi olduğu görülmektedir. Bu bağlamda hoş parametresinde en yüksek puanı alması etkili olmuştur.

F3 kodlu fotoğraf sıkıcı (71), ilginç değil (72) uyumsuz (75) monoton(73) parametrelerinde en yüksek puanı alırken, hoş(19), farklı(13), uyumlu(15) parametrelerinde en düşük puanı almıştır. Ticari levhaların cadde ve sokaklarda; renk, doku, tekstür, şekil ve biçim gibi özellikleri bulunduğu yerin mevcut yapısına uygun şekilde tercih edilmesi kent estetiğine olumlu katkıda bulunmaktadır. Bu bağlamda F3 kodlu fotoğraf ise ticari levhaların görüntü kirliliği oluşturduğu ve bina cephelerini işgal ettiği bir fotoğraftır. 
F8 kodlu fotoğraf uyumlu parametresinde en yüksek(99) puanı alırken, uyumsuz parametresinde en düşük(0) puanı almıştır. F8 kodlu fotoğrafta doğa taklit edilerek daha informal çizgilere yer verilmiştir. Dolayısıyla daha doğaldır. Bu bağlamda F8 kodlu fotoğraf uyumlu parametresinde en yüksek puanı almiştır.

F10 kodlu fotoğraf silik parametresinde en yüksek(58) puanı almıștır. Su öğesi, kamusal park ve meydanlar gibi kentsel çevrelerde inșaa edilmiș su elemanları olup; kent peyzajlarımızda suyun rolünü ortaya koymaktadır. İnsanların suyun özelliklerini dokunma, görme ve ses yoluyla deneyimlemesine olanak sağlarlar dolaysıyla da bu şekilde yaklaşımın arkasındaki gerekçe insanların suyun güzellikleri ile ilişki kurabilecekleri sürdürülebilir ve güzel kentsel açık alanlar üretmektir. Ancak F10 kodlu fotoğrafta ise durum tam tersidir. Dolayısıyla süs havuzları, şelaleler, göletler gibi içinde su barındıran alanların susuz ve atıl bırakılması kentlerde estetik açıdan olumsuz yönde etkilemektedir ve görüntü kirliliği oluşturmaktadır.

F13 kodlu fotoğraf silik parametresinde en düşük (9) puanı almıştır. Projelerde kullanılan objeler çizgi, şekil-form, doku, renk açısından çok önemli bir yere sahiptir. Çünkü çevresiyle denge içinde, uyumlu, birlik ve bütünlük oluşturmuş objeler kentsel tasarımlarda estetik açısından da olumlu katkı sağlayacaktır. F13 kodlu fotoğrafta sadece yapısal malzemeden oluşturulmuş bir objedir bu açıdan silik parametresinde en az puanı almıştır.

F15 kodlu fotoğraf sıkıcı parametresinde en yüksek (71) puanı alırken, ilginç parametresinde en düşük(14) puanı almıştır. Peyzaj mimarı doğal ve yapılı çevrelerin planlama, tasarım, yönetim, koruma ve rehabilitasyonuna sanatsal, bilimsel prensipler ve yeni anlayışlar getirmenin yanı sıra ekolojik çerçeveye odaklanmış kaliteli bir yaşam olanağı da sunmaktadır. F15 kodlu fotoğrafta alanın mevcut hali vardır ve hiçbir peyzaj çalışması yapılmamıştır. Bu bağlamda sıkıcı parametresinde en yüksek puanı almiştır.

F20 kodlu fotoğraf silik parametresinde en yüksek (58) puanı almıştır. Kentsel çevre tasarımlarının vazgeçilmez unsurlarından olan donatı elemanları imal edildikleri malzemenin cinsi, yapısı, dokusu, rengi ve çizgisel özellikleri gibi unsurlarla birlikte estetiklik kavramını ortaya koyarlar. F20 kodlu fotoğrafta bulunan donatı elemanı oldukça sade ve eski bir tasarımdır, günümüz tasarımlarının yanında silik kalmaktadır bu yüzden silik parametresinde en yüksek puanı almıştır.

F22 kodlu fotoğraf ilginç (90), farklı (89) parametrelerinde en yüksek puanı alırken, ilginç değil (2), monoton (3) parametrelerinde en düşük puanı almıştır. F22 kodlu fotoğrafta bulunan donatı elemanları modern çizgileri yansıtan ve alışılmışın dışında bir tasarıma sahiptir. $\mathrm{Bu}$ açıdan ilginç parametresinde en yüksek puanı almıştır.

F26 kodlu fotoğraf abartılı parametresinde en düşük (17) puanı almıştır. Binaların dış cephe kaplama malzemesi ile kaplanması binanın tümünde ısı yalıtımı sağlamak gibi yaralarının yanında estetik açıdan da binanın dış cephe boya renkleri ile boyanıp dekoratif, şık bir görünüm elde edilmesine katkı sağlamaktadır. Dolayısıyla da bina cephe kaplamaları kentlerde hem estetik açıdan hem de kentsel kimlik kazanma açısından oldukça önemlidir. Dolayısıyla F26 kodlu görsel abartı parametresinde en düşük puanı almıştır.

F32 kodlu fotoğraf abartılı parametresinde en yüksek (71) puanı almıștır. F32 kodlu fotoğraf abartı parametresinde en yüksek puanı almıştır ama uyumlu bulunmuştur. Heykelin Ulusal Yükseliş Anıtı kimliğine sahip olması ve alanla bütünleșmesi uyumlu bulunmasında rol oynamaktadır. Dahası Antalya ile bütünleşerek değerlenmiş ve kimlik kazanmış heykelin kent estetiğine katkısı büyüktür.

\section{Tartıșma ve Sonuç}

İnsanların ve diğer canlıların yaşamları boyunca ilişkilerini sürdürdükleri karşılıklı etkileşim içinde oldukları ortamlar çevreyi oluşturmaktadır. Bulunduğumuz çevrelerin fiziki, biyolojik, sosyal, ekonomik ve kültürel ortamları hayatımızın şekillenmesinde katkı sağlarken genel görünümleri de psikojik ve entelektüel ihtiyaçlarımızın karşılanmasına katkı sağlamaktadır. Nitekim F28, F29 ve F30 kodlu fotoğraflarda Cumhuriyet Meydanı, Güllük Caddesi ve Kapalı Yolda bulunan benzer kullanımlar kıyaslanmıştır. Görsellerde alanların genel görünümü değerlendirilmiştir. F28 görseli Kapalı yola, F29 görseli Güllük caddesine, F30 görseli ise Cumhuriyet Meydanına aittir. Alanlar kıyaslandığında F30 kodlu fotoğraf beğenilerinin F28 ve F29 kodlu fotoğraflardan daha fazla olduğu görülmektedir. F28 ve F29 kiyaslanırsa F28 daha fazla oy almıştır fakat F28 ve F29 kodlu fotoğrafların genel görünümlerinin kent estetiğine katkıda bulunabilmesi için restorasyon, iyileşme gibi düzenlemeler yapılması gerekmektedir.

Kentsel tasarımlarda tasarımcıların küçük bir ayrıntı olarak algıladıkları ayrıntılar bile kent estetiği açısından oldukça önemli bir yere sahiptir. Dolayısıyla en küçük tasarımları şekillendirirken bile kullanılan malzeme renk, doku, tekstür, biçim-form yönünden iyi araștırmalı ve yerinde kararlar vermelidir. Nitekim F17,F18 ve F19 kodlu fotoğraflarda Cumhuriyet Meydanı, Güllük Caddesi ve Kapalı Yolda bulunan benzer kullanımlar kıyaslanmıştır. Görsellerde bitki ve ağaç çevresinde kullanılan malzeme görünümü değerlendirilmektedir. F17 görsel Cumhuriyet Meydanında, F18 görsel 
Güllük Caddesinde, F19 görsel Kapalı Yola aittir. Anket katılımcılarının yanıtları incelendiğinde F17 kodlu fotoğraf daha çok beğeni almıștır. F18 ve F19 kodlu fotoğraflara nazaran modern görüntüsünden dolayı kent estetiğine katkısı daha yüksektir.

Peyzaj mimarı doğal ve yapılı çevrelerin planlama, tasarım, yönetim, koruma ve rehabilitasyonuna sanatsal, bilimsel prensipler ve yeni anlayışlar getirmenin yanı sıra ekolojik çerçeveye odaklanmış kaliteli bir yaşam olanağı da sunmaktadır. Bu bağlamda F15 ve F16 kodlu fotoğraflara bakıldığında F15 kodlu fotoğrafta alanın mevcut hali F16 fotoğrafta ise peyzaj düzenlemeleri yapılmış hali görülmektedir. Dolayısıyla açık bir şekilde görülüyor ki F16 kodlu fotoğraf daha yüksek puanlar almıştır. Hali hazır projelendirilmesi gerekli olan yerlerde peyzaj çalışmalarının gerçekleştirilmesi kent estetiğine olumlu katkıda bulunmaktadır.

Projelerde kullanılan objeler çizgi, şekil-form, doku, renk açısından çok önemli bir yere sahiptir. Çünkü çevresiyle denge içinde, uyumlu, birlik ve bütünlük oluşturmuş objeler kentsel tasarımlarda estetik açısından da olumlu katkı sağlayacaktır. Nitekim F13 ve F14 kodlu fotoğraflara bakıldığında F13 kodlu fotoğrafta yapısal malzemeden oluşturulmuş bir obje F14 kodlu fotoğrafta ise topiary sanatını da barındiran bir obje mevcuttur. Uzman anket katılımclarından F13 ve F14 kodlu fotoğrafları kıyaslamaları istendiğinde yakın puanlar alsalar da F14 kodlu fotoğraf daha yüksektir. Tasarımlarda yapısal objelerin bitkilerle birlikte kullanımı kentsel estetiğe katkı sağlayabilir.

Kentsel çevrelerde tasarımlarda kullandığımız bitkiler gerek sonbahar, gerekse ilkbahar renklenmesiyle adeta gözlerimizde renk şöleni oluşturmaktadır. Kentsel estetik hususunda ise bitki renklenmelerinin mevsimsel olarak sınıflandırılamadığı görülmektedir. Nitekim F11 ve F12 kodlu fotoğraflara bakıldığında yaz görüntüsü ve kış görüntüsü kıyaslanmıștır ancak puanlarda büyük bir fark görülmemektedir. $\mathrm{Bu}$ bağlamda yaz görüntüsü de kış görüntüsü de yakın puanlar almış kent estetiğine etkisi bulunmamıştır.

Doğallık özelliklerine sahip çevrenin birçok materyal ile uyumunun kolay olduğu ve bitki türlerinin duyusal algı özelliklerinin kombinasyonunun tasarımlarda çok fazla tercih sebebi olduğu görülmektedir. İnformal çizgiler doğalı çağrıştıran çizgisel formlara sahip iken, formal çizgilerse daha keskin ve köşeli hatlara sahip çizgi formundadır. Nitekim F7 ve F8 kodlu fotoğraflarda bulunan alanların kıyaslanması istenmiştir. Güllük Caddesinde bulunan F7 kodlu fotoğrafta çok formal çizgilere yer verilmiş, doğallıktan uzak bir tasarımdır. F8 kodlu fotoğrafta ise daha informal çizgilere yer verilmiş ve daha doğaldır. Dolayısıyla F8 kodlu fotoğraf daha yüksek puanlar almıştır.
Su öğesi, kamusal park ve meydanlar gibi kentsel çevrelerde inşaa edilmiş su elemanları olup; kent peyzajlarımızda suyun rolünü ortaya koymaktadır. İnsanların suyun özelliklerini dokunma, görme ve ses yoluyla deneyimlemesine olanak sağlarlar dolaysıyla da bu şekilde yaklaşımın arkasındaki gerekçe insanların suyun güzellikleri ile ilişki kurabilecekleri sürdürülebilir ve güzel kentsel açı alanlar üretmektir. $\mathrm{Bu}$ bağlamda $\mathrm{F9}$ ve F10 kodlu fotoğraflarda su öğesinin varlığı kıyaslanmaktadır. Su varlığının bulunmadığı F10 kodlu fotoğraf daha düşük puan almıştır çünkü süs havuzları, şelaleler, göletler gibi içinde su barındıran alanların susuz ve atıl bırakılması kentlerde estetik açıdan olumsuz yönde etkilemektedir ve görüntü kirliliği oluşturmaktadır. Bu açıdan süs havuzları, şelaleler, göletler gibi alanlarda suyun varlığı kentlere de estetik açıdan katkıda bulunacaktır.

Ticari levhaların cadde ve sokaklarda; renk, doku, tekstür, șekil ve biçim gibi özellikleri bulunduğu yerin mevcut yapısına uygun şekilde tercih edilmesi kent estetiğine olumlu katkıda bulunmaktadır. Nitekim F3 ve F4 kodlu fotoğraflarda ticari işletme levhalarına bakılarak kıyaslama yapılması istenmiştir. F3 kodlu fotoğraf Kapalı yolda bulunan karmașı ve görüntü kirliliği oluşturan levhalardan oluşmaktayken F4 kodlu fotoğraf ise Kapalı Yolun bir üst caddesinde yer alan Şarampol Caddesine aittir ve geçtiğimiz yıllarda cadde de sokak iyileștirilmesi yapılmıştır. Dolayısıyla F3 kodlu fotoğraf düşük puanlar alırken F4 kodlu fotoğraf yüksek puanlar almıștır. Ticari levha kirliliği insanları çok rahatsız etmektedir çünkü birçok parametrenin en düşük oyunu görüntü kirliliği olușturan ticari levhaları bünyesinde barındıran F3 kodlu fotoğraf almıștır.

Kent estetiği konusu interdisipliner bir alandır ve peyzaj mimarları, yapı mimarlarını ve şehir plancılarını bünyesinde barındırmaktadır. $\mathrm{Bu}$ noktada disiplinler birlikte hareket etmeli ve halkı düşünerek ortak paydaya gelebilmelidirler. Disiplinler arası çalışma sınırlarına saygı gösterilmeli gerektiğinde fikir paylaşımı yapılmalıdır. Maalesef günümüzde Kent Esteği Konseylerinde genelde yapı mimarları ön plana çıkmakta ve peyzaj mimarlarına yer verilmemektedir. Nitekim Peyzaj mimarlarına da bu ve benzeri konseylerde yer verilmelidir. Bunun değerlendirilmesi mesleki açıdan da bir kazanım olacaktır.

Ticari levha kirliği kent estetiğine olumsuz katkıda bulunmaktadır. Bu bağlamda işletmeler tek tip levha kullanımına geçmelidir. Aynı zamanda binaların diş cephesinin genel görünümlerinin kent estetiğine katkıda bulunabilmesi için restorasyon, iyileştirme gibi düzenlemeler yapılması gerekmektedir. Kimliksiz ya da anlam içeriğine sahip olmadan kullanılan objeler alandan soyutlanmakta ve yabancılaşmaktadır ve zamanla göze hitap etmemektedir. $\mathrm{Bu}$ açıdan kullandığımız obje ve 
heykellerin alanla entegrasyonunu göz önünde bulundurulmalı ve tercihlerin o yönde yapmasına özen gösterilmelidir.

Kent mobilyaları ve donatı elemanları seçiminde çizgi günümüz koşullarına uyan modern, işlevsel, ekonomik ve ergonomik tercihler olmalıdır. Kent mobilyaları ve donatılar kentlerin bel kemiğini oluşturmaktadır. Doğru tercihlerimiz kent estetiğine olumlu katkıda bulunacaktır.

Süs havuzları, şelaleler, göletler gibi alanlar susuz bırakılmamalıdır. Su varlığının bulunmadığı süs havuzları, şelaleler, göletler gibi içinde su barındıran alanların susuz ve atıl bırakılması kentlerde estetik açıdan olumsuz yönde etkilemektedir ve görüntü kirliliği oluşturmaktadır. Bu açıdan süs havuzları, şelaleler, göletler gibi alanlarda suyun varlığı kentlere de estetik açıdan katkıda bulunacaktır.

Doğal yakın tasarımlar daha estetik bulunmaktadır. Tasarımlarımıza doğadaki düzeni takip ederek yön vermeliyiz. Gereksiz büyük, sert zemine oturtulmuş tek tip bitki türlerinden oluşan tasarımlardan uzak durulmall, daha zengin bitkisel tasarımlara yer verilmelidir. Tasarımlarda yapısal objelerin bitkilerle birlikte kullanımı kentsel estetiğe katkı sağlayabilir.

Sonuç olarak mekâna, kente ve kentsel mekâna ilişkin beğeni düzeyinin yükseltilmesi, estetik eğitimin kendisi, yalnızca algı düzeyi ile sınırlanmış bir anlayışa indirgenemez. Estetik anlayışımız, estetiğin bir 'algı' ve bir 'beğeni yargısı' ya da 'hazlar kuramı' olarak gören Kantçı estetiğin ötesindedir. Önemli olan kentsel yaşamın güzelliğin alanına sokulması (kentsel estetik) ve dönüştürülmesidir. Yani estetiğin bizzat yaşamın, toplu yaşamın içine sokulmasıdır. Estetiğin alanı, yalnızca gerçeğin estetik yoldan kavranması ve güzelliğin bağlı olduğu yasaların bulunması ile sınırlı görülemez, esas olan gerçeğin biçimlendirilmesi ve dönüştürülmesidir. Yani kentsel estetiği alanı edilgen bir etkinlik değildir [5].

\section{Kaynakça}

[1] Sevinç, M. 1999. Postmodernizm ve kent. Birikim Dergisi, 124, 54-59.

[2] Kumbaracıbaşı, C. 1991. Kent, estetik, Ankara, 2000'li yıllar için Ankara kenti'nin açık ve yeşil alan sistemi ne olmalıdır?. Ankara Büyükşehir Belediyesi\&Peyzaj Mimarlığı Derneği Sempozyum Bildirileri Ortak Yayını, 29/31 Mayıs, Ankara, 65-67.

[3] Dede, E. Ö. 1997. Mekanın algılanma olgusu ve insan-hareket-zaman faktörlerinin etkisi. İstanbul Teknik Üniversitesi, Fen Bilimleri Enstitüsü, Yüksek Lisans Tezi, İstanbul.

[4] Kalın, A. 2004. Çevre tercih ve değerlendirmesinde görsel kalitenin belirlenmesi ve geliştirilmesi Trabzon sahil bandı çrneği. Karadeniz Teknik Üniversitesi, Fen Bilimleri Enstitüsü, Doktora Tezi, Trabzon.

[5] Keskinok, H. Ç 2007. Kentsel Estetik Üzerine. http://www.mimarlikdergisi.com/index.cfm?sa $\mathrm{yfa}=$ mimarlik\&DergiSayi $=52 \&$ RecID $=1295$ (Erişim Tarihi: 10.10.2019).

\section{Ekler}

Ek A. Kentsel çevrede estetik değerlendirmesi: Muratpaşa ili örneğine ilişkin halk ve uzman kullanıcı anket değerlendirmesi

1.Cinsiyetiniz? *

$\bigcirc$ Kadın $\bigcirc$ Erkek

2.Yaşınız ? *

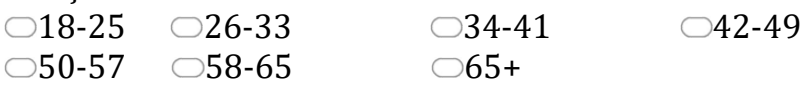

3.Eğitim durumunuz ? *

○Ilk Öğretim $\bigcirc$ Orta Öğretim (Lise) $\bigcirc$ Lisans

$\checkmark$ Yüksek Lisans $\bigcirc$ Doktora

4.İş durumunuz ? *

Çalışıyor $\quad$ Çalışmıyor

5.Mesleğiniz ? *

6.Ekonomik geliriniz? ${ }^{*}$

$\bigcirc . .<2.500 \quad \bigcirc 2.500-5.000 \quad \bigcirc 5.000<\ldots$

7.Kapalı yolu kullanma sıklığınız ? *

$\checkmark$ Hergün $\bigcirc$ Haftada iki $\bigcirc$ Haftada bir $\bigcirc$ Ayda iki-üç $\checkmark$ Ayda bir $\bigcirc$ İki ayda bir $\bigcirc$ İlk defa

8.Cumhuriyet Meydanını kullanma sıklığınız ? *

$\checkmark$ Hergün $\bigcirc$ Haftada iki $\bigcirc$ Haftada bir $\bigcirc$ Ayda iki-üç $\bigcirc$ Ayda bir $\bigcirc$ İki ayda bir $\bigcirc$ İlk defa

9.Güllük caddesini kullanma sıklığınız ? *

$\checkmark$ Hergün $\bigcirc$ Haftada iki $\bigcirc$ Haftada bir $\bigcirc$ Ayda iki-üç $\bigcirc$ Ayda bir $\bigcirc$ İki ayda bir $\bigcirc$ İlk defa

10.Kapalı yolu hangi saat dilimlerinde daha çok kullaniyorsunuz? (Birden fazla seçenek işaretleyebilirsiniz.) *

$\begin{array}{lr}\square 07.00-12.00 & \square 12.00-18.00 \\ \square 18.00-24.00 & \square 24.00-07.00\end{array}$

11.Cumhuriyet meydanını hangi saat dilimlerinde daha çok kullanıyorsunuz? (Birden fazla seçenek işaretleyebilirsiniz.) *

$\begin{array}{ll}\square 07.00-12.00 & \square 12.00-18.00 \\ \square 18.00-24.00 & \square 24.00-07.00\end{array}$

12.Güllük caddesini hangi saat dilimlerinde daha çok kullanıyorsunuz? (Birden fazla seçenek işaretleyebilirsiniz.) *

$\square 07.00-12.00 \quad \square 12.00-18.00$

$\square 18.00-24.00 \quad \square 24.00-07.00$ 
13.Kapalı yol sizde nasıl bir psikolojik etki uyandirıyor? *

$\bigcirc$ Sıkıntı ve hayal kırıklı̆̆ı

$\bigcirc$ Mutluluk verici

$\bigcirc$ Rahatlatıcı

\section{$\bigcirc$ Heyecan verici \\ $\checkmark$ Korku ve kaygı verici \\ Güven verici}

14.Cumhuriyet meydanı sizde nasıl bir psikolojik etki uyandiriyor? ${ }^{*}$
$\checkmark$ Sıkıntı ve hayal kırıklığı
Mutluluk verici
$\bigcirc$ Rahatlaticl
$\bigcirc$ Heyecan verici
Korku ve kaygı verici
$\checkmark$ Güven verici

15.Güllük caddesi sizde nasıl bir psikolojik etki uyandırıyor ?*
$\bigcirc$ Sıkıntı ve hayal kırıklığı
$\bigcirc$ Mutluluk verici
Rahatlatıcı
$\checkmark$ Heyecan verici
$\bigcirc$ Korku ve kaygı verici
$\checkmark$ Güven verici

16.Kapalı yoldaki fonksiyonlar beklentilerinizi (memnuniyet durumu) karşıllyor mu? *

$\bigcirc$ Hiç memnun değilim $\bigcirc$ Memnun değilim

$\checkmark$ Fikrim yok $\bigcirc$ Çok memnunum $\odot$ Memnunum

17.Cumhuriyet meydanındaki fonksiyonlar beklentilerinizi (memnuniyet durumu) karşılıyor mu ?* $^{*}$

$\bigcirc$ Hiçmemnun değilim $\bigcirc$ Memnun değilim

$\checkmark$ Fikrim yok $\bigcirc$ Çok memnunum $\bigcirc$ Memnunum

18.Güllük caddesindeki fonksiyonlar beklentilerinizi (memnuniyet durumu) karşıllyor mu ? *

$\bigcirc$ Hiç memnun değilim $\bigcirc$ Memnun değilim

$\checkmark$ Fikrim yok $\bigcirc$ Çok memnunum $\bigcirc$ Memnunum

19.Kapalı yolda en beğendiğiniz karakteristik özellik

? (Birden fazla seçenek işaretleyebilirsiniz.) *

$\square$ Sokaklar ve cadde kimliği $\square$ Bitki örtüsü $\square$ Su öğesi

$\square$ Mimari yapı $\square$ Donatılar $\square$ Diğer

20.Cumhuriyet meydanında en beğendiğiniz karakteristik özellik? (Birden fazla seçenek işaretleyebilirsiniz.) *

$\square$ Sokaklar ve cadde kimliği $\square$ Bitki örtüsü $\square$ Su öğesi

$\square$ Mimari yapı $\square$ Donatılar $\square$ Diğer

21.Güllük caddesinde en beğendiğiniz karakteristik özellik? (Birden fazla seçenek işaretleyebilirsiniz.) *

$\square$ Sokaklar ve cadde kimliği $\square$ Bitki örtüsü $\square$ Su öğesi

$\square$ Mimari yapı $\square$ Donatılar $\square$ Diğer

22.Kapalı yolu kullanma amacınız nelerdir ?(Birden fazla seçenek ișaretleyebilirsiniz.) *

$\square$ Temiz hava almak $\quad \square$ Dinlenmek ve rahatlamak

$\square$ Birileriyle buluşmak $\square$ Günlük işlerimi halletmek

$\square$ Alışveriş yapmak $\quad \square$ Etrafı seyretmek $\quad \square$ Diğer

23.Cumhuriyet meydanını kullanma amacınız nelerdir ?(Birden fazla seçenek işaretleyebilirsiniz.) *

$\square$ Temiz hava almak $\quad \square$ Dinlenmek ve rahatlamak

$\square$ Birileriyle buluşmak $\square$ Günlük işlerimi halletmek

$\square$ Alışveriş yapmak $\quad \square$ Etrafı seyretmek $\quad \square$ Diğer
24.Güllük caddesini kullanma amacınız nelerdir?

(Birden fazla seçenek işaretleyebilirsiniz.) *

$\square$ Temiz hava almak $\square$ Dinlenmek ve rahatlamak

$\square$ Birileriyle buluşmak $\square$ Günlük işlerimi halletmek

$\square$ Alışveriş yapmak $\square$ Etrafı seyretmek $\square$ Diğer

25.Kapalı yolun nasıl olmasını isterdiniz ? *

$\bigcirc$ Daha renkli $\bigcirc$ Daha renksiz $\bigcirc$ Daha kompleks

$\bigcirc$ Daha basit $\bigcirc$ Daha büyük $\bigcirc$ Daha küçük

$\odot$ Daha doğal $\odot$ Daha yapay

26.Cumhuriyet meydanının nasıl olmasını isterdiniz ?

$\bigcirc$ Daha renkli $\bigcirc$ Daha renksiz $\bigcirc$ Daha kompleks

Daha basit Dahabüyük $\bigcirc$ Daha küçük

$\checkmark$ Daha doğal $\bigcirc$ Daha yapay

27.Güllük caddesinin nasıl olmasını isterdiniz ? *

$\bigcirc$ Daha renkli $\bigcirc$ Daha renksiz $\bigcirc$ Daha kompleks

$\bigcirc$ Daha basit $\bigcirc$ Dahabüyük $\bigcirc$ Daha küçük

$\bigcirc$ Daha doğal $\bigcirc$ Daha yapay

28.Kapalı yolda hangi düzenlemelere yer verilmelidir

? (Birden fazla seçenek işaretleyebilirsiniz.) *

$\square$ Su öğeleri $\square$ Plastik objeler $\square$ Bitkiler $\square$ Donatılar

29.Cumhuriyet meydanında hangi düzenlemelere yer verilmelidir? (Birden fazla seçenek işaretleyebilirsiniz.) *

$\square$ Su öğeleri $\square$ Plastik objeler $\square$ Bitkiler $\square$ Donatılar

30.Güllük caddesinde hangi düzenlemelere yer verilmelidir? (Birden fazla seçenek işaretleyebilirsiniz.) *

$\square$ Su öğeleri $\square$ Plastik objeler $\square$ Bitkiler $\square$ Donatılar

31.Estetik bir meydan sizce nasıl olmalıdır ? *

$\checkmark$ Göze hoş görünmeli $\bigcirc$ Birçok kullanım içerme

$\checkmark$ Çevre içinde farkedilmeli $\bigcirc$ Sanatsal değeri olmalı

$\checkmark$ Doğal malzemeler kullanılmalı

32.Estetik bir cadde sizce nasıl olmalıdır ? *

$\checkmark$ Göze hoş görünmeli $\bigcirc$ Birçok kullanım içerme

$\bigcirc$ Çevre içinde farkedilmeli $\bigcirc$ Sanatsal değeri olmalı

$\checkmark$ Doğal malzemeler kullanılmalı

33.Kapalı yolda hoşlandığınız şeyler nelerdir ? *

34.Cumhuriyet meydanında hoşlandığınız şeyler nelerdir ?*

35.Güllük caddesinde hoşlandığınız şeyler nelerdir ? *

36.Kapalı yolda hoşlanmadığınız şeyler nelerdir ? *

37.Cumhuriyet meydanında hoşlanmadığınız şeyler nelerdir ?*

38.Güllük caddesinde hoşlanmadığınız şeyler nelerdir ?* 
EK B. Kentsel Cevrede Estetik Değerlendirmesi: Muratpașa İli Örneğine İlişkin Uzman Kullanıcıların Foto-Anket Değerlendirmesinde Yer Alan Fotoğraflar
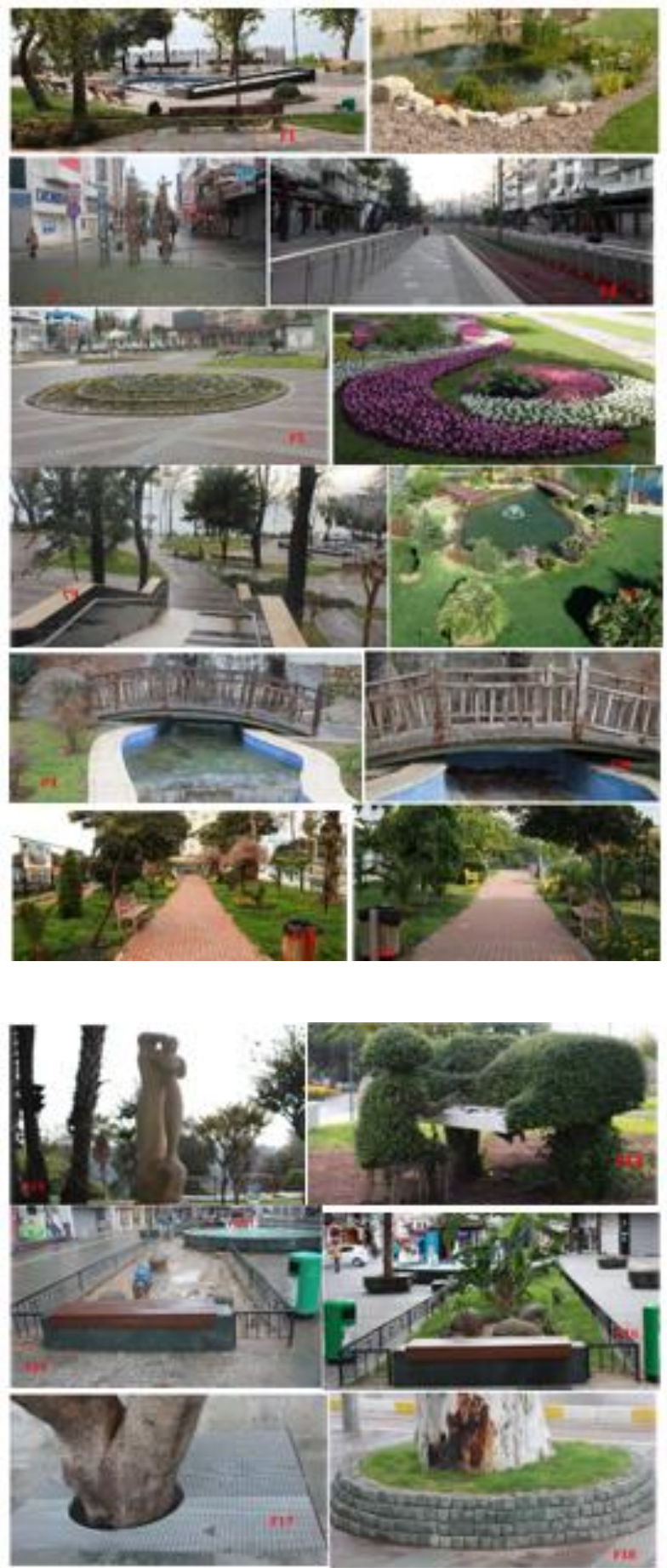
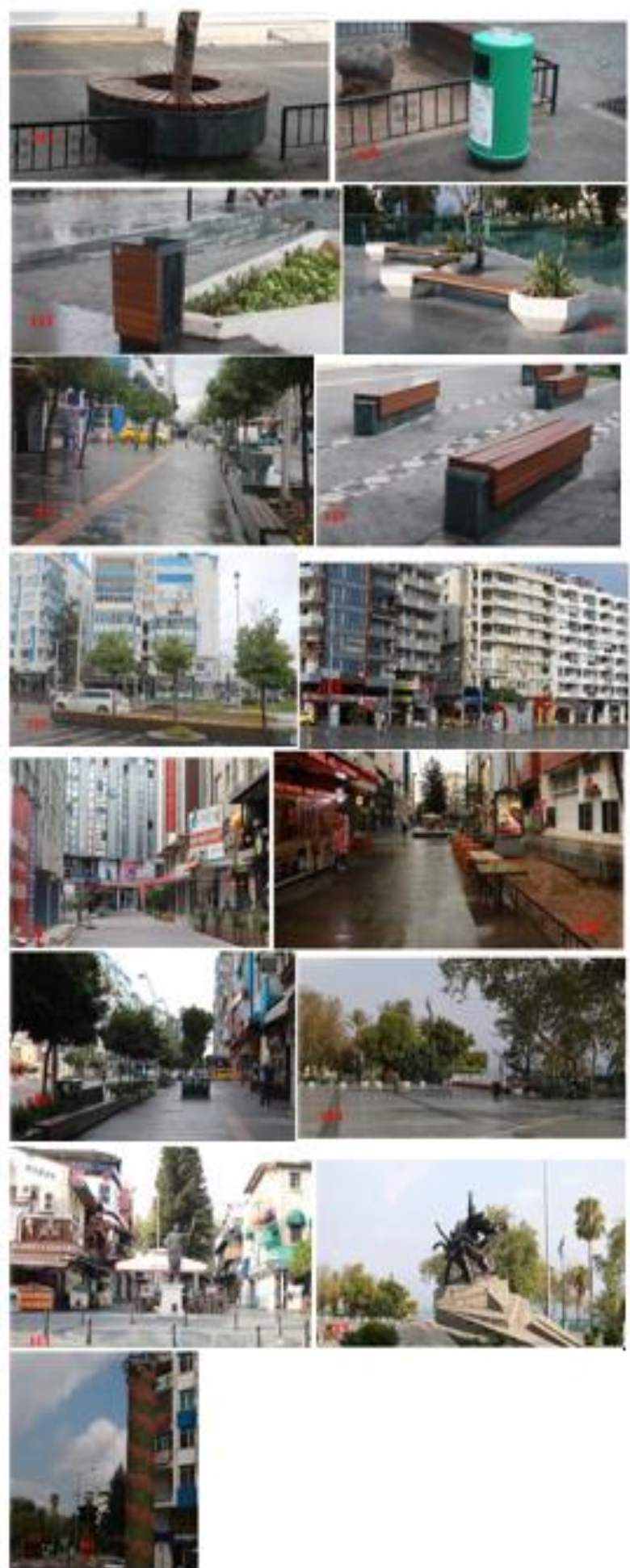